\title{
Influence of furanone C-30 on cell viability of Human Oral Keratinocytes
}

Morsch, CS; Herrero, ER; Passoni, BB; Magini, RS; Pimenta, AL; de Souza, JCM; Teughels, W; Benfatti, CAM

Federal University of Santa Catarina / KU Leuven

\section{Abstract}

Background and aim: Furanone C-30 is one from a series of synthesized halogeno-furanone compounds whose structure is similar to the bromated furanones produced by marine algae Delisea pulchra. Such compounds acts controlling the early steps of biofilm formation. Not killing the pathogens but disrupting the biofilm thus avoiding the development of bacterial resistance. This study aimed to evaluate the effect of different concentrations of furanone C-30 on cell viability of Human Oral Keratinocytes. Methods: Immortalized human oral keratinocyte cell line (HOK-18A) was grown in cell culture flasks with keratinocyte growth medium (KSFM) supplemented as manufacturer's instructions at $37^{\circ} \mathrm{C}$ humidified atmosphere containing $5 \%$ CO2. Cells were seeded at $20.000 \mathrm{cell} / \mathrm{cm}^{2}$ at the bottom of 96 well-plate. The cells were exposed to furanone C-30 dissolved in $95 \%$ ethanol and to each well to give the final concentrations of $128,64,60,40,35,32,30,25,20,16,15,10,8,4,2,1$ e $0,5 \mathrm{\mu g} / \mathrm{ml}$. As positive control growth medium and negative control Triton $X-100$. The plate was incubated in the same conditions for $20 \mathrm{~h}, \mathrm{XTT}$ was added, after $4 \mathrm{~h}$ the optical density was measured using a microplate reader. Experiment was repeated in 3 different days. Results: The viability of HOK 18-A was higher then $50 \%$ in the concentrations of $32,30,25,20,16,15,10,8,4,2,1 \mathrm{e}$ $0,5 \mathrm{\mu g} / \mathrm{ml}$ of furanone $\mathrm{C}-30$. The cell viability was not affected at the concentrations lower then $10 \mu \mathrm{g} / \mathrm{ml}(10 \mu \mathrm{g} / \mathrm{ml} 114,34 \%$ SD 5,76$)$. In the higher concentrations of furanone the cell viability was affected. At $128 \mu \mathrm{g} / \mathrm{ml}$ the viability was $36,16 \%$ SD $1,26,64 \mu \mathrm{g} / \mathrm{ml} 34,04 \%$ SD 13,69 , and $35 \mu \mathrm{g} / \mathrm{ml} 40,28 \%$ SD 24,88 . The ethanol that was used to dilute the furanone C-30 was also tested and the cell viability was not affected $(97,41 \%$ SD 8,50$)$. Conclusion: The furanone C-30 when in contact with HOK 18-A cells showed more than $50 \%$ of cell viability in the concentrations of $32,30,25,20,16,15,10,8,4,2,1$ e $0,5 \mu \mathrm{g} / \mathrm{ml}$. The furanone can be used safely to try to inhibit the biofilm formation in the oral cavity in this concentrations.

\section{Background and Aim}

Biofilm formation is mediated by an intercellular communication system known as quorum sensing (QS). A new generation of antimicrobial drugs that act controlling the early steps of biofilm formation, disrupting bacterial QS, has been proposed as a new anti-biofilm infection strategy. QS inhibitors as bromated furanones produced by the marine red alga Delisea pulchra act disrupting QS, inhibiting biofilm formation. Halogeno-furanone compounds with similar structures to those found in D. pulchra, as furanone C-30, do not kill the pathogens directly, but disrupt the biofilm organization avoiding development of bacterial resistance to the drug. The main aim of this study was to evaluate the effect of different concentrations of furanone $\mathrm{C}-30$ on cell viability of Human Oral Keratinocytes by XTT test.

\section{Methods and Materials}

Immortalized human oral keratinocyte cell line (HOK-18A) seeded at the bottom of cell culture flasks with keratinocyte growth medium (KSFM) supplemented as manufacturer's instructions at $37^{\circ} \mathrm{C}$ humidified atmosphere containing 5\% CO2 and 95\% humidity. Culture media were refreshed 3 times a week. When HOK-18A reached $80 \%$ of confluence the cells were harvested with Trypsin. Cells were seeded at 20.000 cell/ $\mathrm{cm}^{2}$ density at the bottom of 96 well-plates. The cells were exposed to 50 $\mu \mathrm{L}$ of furanone $\mathrm{C}-30$ dissolved in $95 \%$ ethanol and added to each well to give a final concentration of 128, 64, 60, 40, 35, 32, 30, 25, 20, 16, 15, $10,8,4,2,1$ e $0,5 \mu \mathrm{g} / \mathrm{ml}$. As positive control growth medium and negative control Triton $\mathrm{X}-100$. The plate was incubated in the same conditions for $20 \mathrm{~h}$, when $50 \mu \mathrm{l}$ of XTT and $1 \mu \mathrm{l}$ of PMS was added in each well. The plate was covered with aluminium foil to avoid light contact and incubated again for $4 \mathrm{~h}$ more. The optical density was measured in filter $450 \mathrm{~nm} /$ $630 \mathrm{~nm} / 690 \mathrm{~nm}$ using a microplate reader. Experiment was repeated in 3 different days.

\section{Results}

The viability of HOK 18 -A was higher then $50 \%$ in the concentrations of $32,30,25,20$ $16,15,10,8,4,2,1$ e $0,5 \mu \mathrm{g} / \mathrm{ml}$ of furanone C- 30 . At $32 \mu \mathrm{g} / \mathrm{ml}$ it was $50,37 \%$ of cell viability with a standart deviation (SD) of 19,67 , at $30 \mu \mathrm{g} / \mathrm{ml} 65,68 \%$ SD $8,20,25 \mu \mathrm{g} / \mathrm{ml}$ $72,28 \%$ SD $8,48,20 \mu \mathrm{g} / \mathrm{ml} 81,80 \%$ SD $9,86,16 \mu \mathrm{g} / \mathrm{ml} 91,87 \%$ SD $10,40,15 \mu \mathrm{g} / \mathrm{ml}$ $94,98 \%$ SD $6,94,10 \mu \mathrm{g} / \mathrm{ml} 114,34 \%$ SD $5,76,8 \mu \mathrm{g} / \mathrm{ml} 111,49 \%$ SD $7,37,4 \mu \mathrm{g} / \mathrm{ml} 112,01 \%$ SD $7,80,2 \mu \mathrm{g} / \mathrm{ml} 108,10 \%$ SD $10,68,1 \mu \mathrm{g} / \mathrm{ml} 107,86 \%$ SD 5,06 and $0,5 \mu \mathrm{g} / \mathrm{ml} 109,73 \%$ SD 5,44. In the higher concentrations of furanone the cell viability was affected. At $128 \mu \mathrm{g} / \mathrm{ml}$ the viability was $36,16 \%$ SD $1,26,64 \mu \mathrm{g} / \mathrm{ml} 34,04 \%$ SD $13,69,60 \mu \mathrm{g} / \mathrm{ml}$ $33,78 \%$ SD $14,30,40 \mu \mathrm{g} / \mathrm{ml} 34,83 \%$ SD 28,44 and $35 \mu \mathrm{g} / \mathrm{ml} 40,28 \%$ SD 24,88. The ethanol that was used to dilute the furanone $\mathrm{C}-30$ was also tested and the cell viability was not affected $(97,41 \%$ SD 8,50$)$

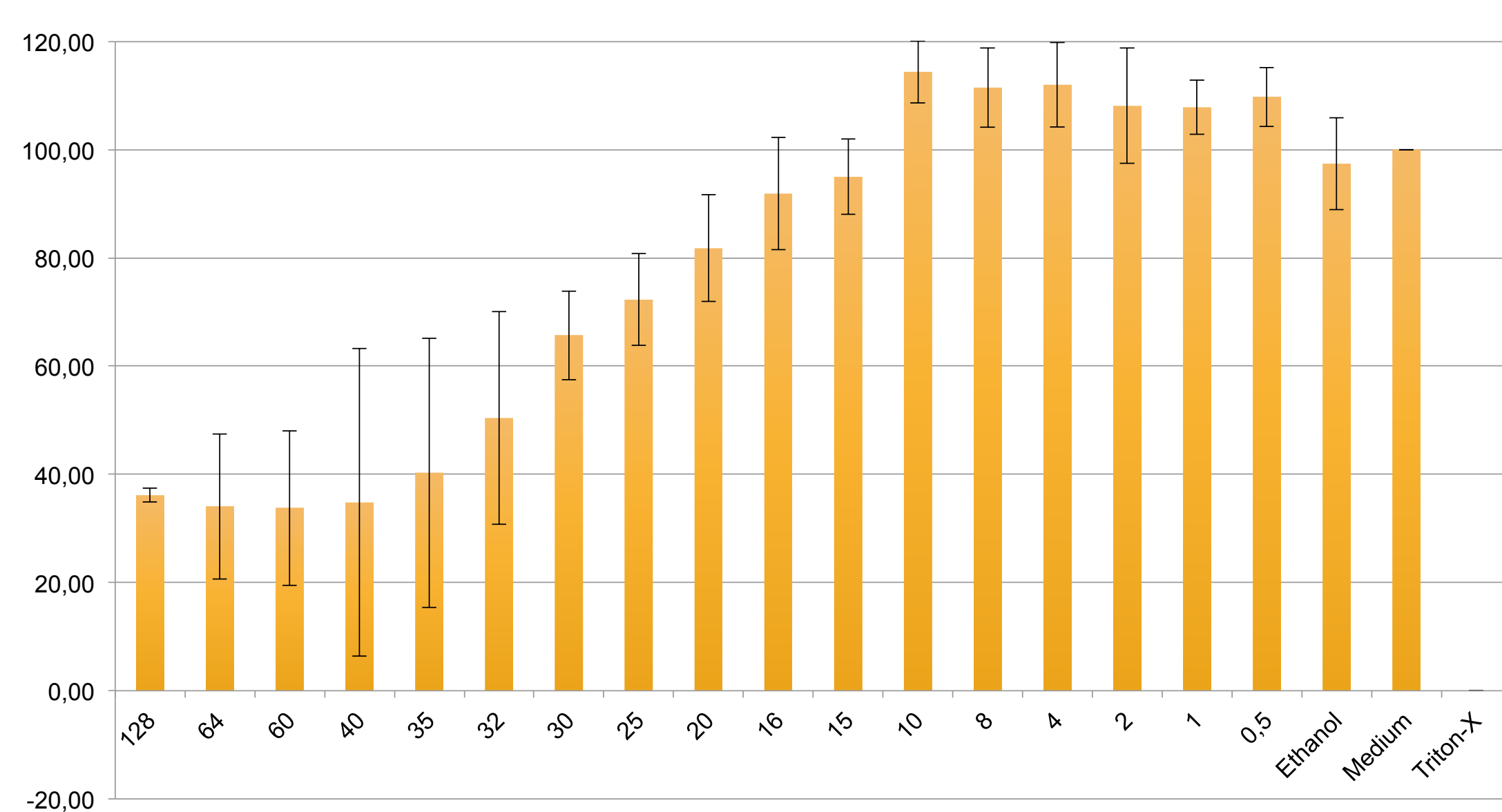

$-20,00$

\section{Conclusions}

The furanone C-30 when in contact with HOK 18-A cells showed more than $50 \%$ of cell viability in the concentrations of $32,30,25,20,16,15$, $10,8,4,2,1$ e $0,5 \mu \mathrm{g} / \mathrm{ml}$. The furanone C-30 can be used safely to try to inhibit the biofilm formation in the oral cavity in this concentrations.

\section{References}

1. Davies D. (2003) Understanding biofilm resistance to antibacterial agents Nat Rev Drug Discov 2 (2):114-22.

2. Olson ME, Ceri H, Morck DW, Buret AG, Read RR. (2002) Biofilm bacteria: Formation and comparative susceptibility to antibiotics. Can J Vet Res 66(2):86-92.

3. Pereira UA, Barbosa LC, Maltha CR, Demuner AJ, Masood MA, Pimenta AL. (2014) y-Alkylidene-y-lactones and isobutylpyrrol-2(5H)-ones analogues to rubrolides as inhibitors of biofilm formation by gram-positive and gram-negative bacteria. Bioorg Med Chem Lett 15;24(4):1052-6.

4. Prosser JI. Quorum sensing in biofilms. In: Newman HN, Wilson M, ed. Dental plaque revisited. Cardiff: Bioline, 1999: 79-88. 